\title{
A pathophysiological study of the intestinal . manifestations of a vasoactive intestinal peptide, calcitonin, and catecholamine-secreting tumour
}

\author{
I W BOOTH, T R FENTON, P J MILLA, AND J T HARRIES* \\ From the Gastroenterology Unit, The Hospital for Sick Children, Great Ormond Street, London, and the \\ Department of Child Health, Institute of Child Health, Guilford Street, London
}

\begin{abstract}
SUMMARY A three year old girl with severe watery diarrhoea and a vasoactive intestinal peptide, calcitonin, and catecholamine-secreting supra-renal ganglioneuroblastoma is reported. Steadystate perfusion studies showed the jejunum to be in a net secretory state with respect to water, sodium, and chloride at low concentrations $(2 \mathrm{mmol} / \mathrm{l})$ of glucose whereas higher concentrations $(56 \mathrm{mmol} / \mathrm{l})$ reversed secretion to absorption; transmural rectal potential difference was increased (lumen negative); $\mathrm{Na}^{+}$absorption by the rectum was impaired and secretion of potassium and bicarbonate excessive. Motility studies showed prolonged, slowly propagated migrating motor complexes with abnormal runs of non-propagated contractions in the fasting state. During perfusion with glucose, no postprandial activity occurred. These results suggest that diarrhoea results from small intestinal secretion with impaired colonic function and that tumour products may have a direct effect on intestinal motility.
\end{abstract}

Plasma concentrations of vasoactive intestinal peptide (VIP) are raised in most, although not all, patients with the Verner-Morrison or WDHA syndrome (watery diarrhoea, hypokalaemia, and achlorhydria). Since Bloom and his colleagues first reported raised levels of VIP in six patients with diarrhoea and non-B, islet cell pancreatic tumours in $1973,{ }^{1}$ a number of reports have documented a similar association. ${ }^{2} 3$ There is evidence that VIP and calcitonin are at least two of the mediators of the diarrhoea seen in this syndrome. For example, infusion of VIP into healthy pigs, sufficient to produce plasma concentrations comparable with those found in the presence of VIP and calcitoninsecreting tumours, produced severe watery diarrhoea and hypokalaemia. ${ }^{4}$ Furthermore, infusion of VIP into healthy human volunteers sufficient to produce comparable plasma concen-

Address for correspondence: Dr I W Booth, Department of Child Health, Institute of Child Health, 30 Guilford Street, London WC1N 1EH.

* Since submitting this paper Professor Harries has unfortunately died.

Received for publication 29 December 1982 trations, resulted in chloride secretion and reduced sodium and water absorption in the jejunum. ${ }^{5}$ Similarly, infusion of calcitonin into human volunteers resulted in jejunal secretion of water and electrolytes. ${ }^{6}$

At the present time there are only two reported studies concerned with the pathophysiology of the diarrhoea in patients with VIP and calcitoninsecreting tumours, and these were in two adults with pancreatic tumours. ${ }^{78}$ In this paper, we report studies of small and large intestinal transport, and small intestinal motility in a three year old girl with protracted watery diarrhoea and a VIP, calcitonin, and catecholamine-secreting ganglioneuroblastoma. No similar study of small intestinal motility in patients with functionally active tumours has been previously reported.

\section{Case history}

The patient, a girl, first became unwell shortly before her third birthday, when she and her parents developed profuse watery diarrhoea. In contrast to 
her parents, whose symptoms resolved within 48 hours, the diarrhoea persisted, and six weeks later, because of continuing diarrhoea, she was admitted to her local hospital; marked abdominal distention was present with small and large bowel fluid levels on a plain abdominal film. The diarrhoea persisted and she was transferred to the Gastroenterology Unit at the Hospital for Sick Children, Great Ormond Street, London. Examination revealed a healthy looking, normotensive girl with slight abdominal distention; height and weight were both on the 10th centile.

Despite receiving nil by mouth she passed up to $600 \mathrm{ml}$ of watery stool per day $(40 \mathrm{ml} / \mathrm{kg} / \mathrm{day})$ and faecal losses of electrolytes were large (sodium 105, potassium 42 , chloride 51 , bicarbonate $71 \mathrm{mmol} / \mathrm{l}$ ). Urinary losses of water and electrolytes were appropriately diminished. Hypokalaemia (plasma potassium $2.7 \mathrm{mmol} / \mathrm{l}$ ) was present and a mild metabolic acidosis (capillary sample: $\mathrm{pH} 7 \cdot 3 ; \mathrm{pO}_{2}$ $69 ; \mathrm{pCO}_{2} 34 \mathrm{~mm} \mathrm{Hg}$; standard bicarbonate $17 \cdot 1$ $\mathrm{mmol} / \mathrm{l}$ ) but other plasma electrolytes and urea were normal (sodium 140, chloride 108 , urea $5 \cdot 1 \mathrm{mmol} / \mathrm{l}$ ). Plasma glucose and calcium concentrations were within the normal range. A plain abdominal film showed small and large bowel distension and fluid levels, but no other abnormalities were detected on barium meal and follow through, barium enema, or colonoscopy. Urinary catecholamine metabolites (4-hydroxy,3-methoxymandelic acid:creatinine ratio, $38.8(5.6 \pm 2.9)$ and the concentration of plasma noradrenalin $(2459 \mathrm{pg} / \mathrm{ml}(150-350))$ were both considerably raised. Plasma calcitonin was raised at $0.73 \mathrm{ng} / \mathrm{l}(<0.08)$ and plasma VIP was grossly and consistently raised between 100 and 164 $\mathrm{pmol} / \mathrm{l}$ plasma (normal <30). Concentrations of pancreatic polypeptide, gastrin, glucagon, and somatostatin were normal. An intravenous pyelogram and abdominal ultrasound showed the presence of a right suprarenal mass.

At laparotomy, an encapsulated $4 \mathrm{~cm}$ tumour, adjacent to the upper pole of the right kidney, was resected. The tumour had the histological appearances of a ganglioneuroblastoma. Most ganglion cells were well differentiated, but small numbers of less well differentiated cells were also present. VIP-containing cells were observed immunocytochemically although the cells were poorly granulated and reactivity weak. Postoperatively, there was y dramatic resolution of the diarrhoea as well as abdominal distention, hypokalaemia, and acidosis. Plasma VIP concentrations returned to normal within one hour of tumour resection. Twō years after surgery plasma concentrations of FiP aund urinary catecholamines are normal and she remains well with no evidence of tumour recurrence.

\section{Methods}

\section{SUBJECTS}

(a) Jejunal perfusion

Control subjects comprised eight children aged 10 months to 9 years, who were referred with suspected malabsorption but in whom, after extensive investigation, a diagnosis of irritable bowel syndrome was made.

\section{(b) Jejunal motility}

Control subjects comprised nine children, aged 8 months to 7 years who were undergoing small intestinal intubation for the investigation of gastrointestinal symptoms but who were subsequently shown to have no organic pathology.

\section{(c) Rectal transport}

Control subjects comprised seven children, aged 4 months to $2 \frac{1}{2}$ years, three girls, four boys, weight $5-16 \mathrm{~kg}$ and height $62-78 \mathrm{~cm}$, with no evidence of large bowel disease (two hiatus herniae, three feeding problems, and two short stature), a normal jejunal mucosa on light microscopy and no demonstrable evidence of malabsorption. The rectum and sigmoid colon appeared endoscopically normal in all subjects.

TRANSPORT, MOTILITY, AND POTENTIAL

DIFFERENCE STUDIES

Studies of jejunal transport and motility, and of rectal transport and potential difference were performed, approval for which had been obtained from the Standing Committee on Ethical Practice of the Hospital for Sick Children. Informed written consent was obtained from the patients' parents.

\section{JEJUNAL TRANSPORT}

Net rates of jejunal transport, water, sodium, chloride, bicarbonate, potassium, and glucose were measured using a steady-state perfusion technique. The proximal $20 \mathrm{~cm}$ of jejunum was perfused using a double-lumen tube, at a rate of $8 \mathrm{ml} / \mathrm{min}$ as previously described. ${ }^{9}$ Following a 30 minute equilibration period, effluent was collected on ice in 10 minute aliquots for a further 30 minutes. The solution perfused contained either $2 \mathrm{mmol} / 1$ or 56 $\mathrm{mmol} / \mathrm{l}$ glucose, fructose $20 \mathrm{mmol} / \mathrm{l}$, polyethylene glycol $4000(3 \mathrm{~g} / \mathrm{l}), \mathrm{KCl}(4 \mathrm{mmol} / \mathrm{l})$, and $\mathrm{Na} \mathrm{HCO}_{3}$ (25 mmol/l). Their osmolalities were adjusted to 285-290 mOsm/kg by the addition of $\mathrm{NaCl} ; \mathrm{pH}$ was adjusted to $7 \cdot 0$ by gassing with $\mathrm{CO}_{2}$. The solutions were perfused in ascending order of concentration, with a 30 minute equilibration period between each. 
SMALL INTESTINAL MOTILITY

Small intestinal motility was recorded in the 2 nd and 4th parts of the duodenum and proximal jejunum before and during the perfusion study using a triple lumen tube and Gaeltec Mark II Luerlock transducers. Each lumen was perfused with $0.9 \%$ saline at rate of $0.1 \mathrm{ml} / \mathrm{min}$ by an Arndorfer constant pressure perfusion pump.

\section{RECTAL TRANSPORT}

Net rectal transport of sodium, chloride, potassium, and bicarbonate with simultaneous monitoring of transmural potential difference was measured using a modification of the non-equilibrium dialysis method of Edmonds ${ }^{10}$ as previously described.

\section{ANALYSES AND CALCULATIONS}

Samples of jejunal perfusate and effluent and rectal dialysis bag contents were analysed for the following: sodium and potassium by flame photometry (Corning 430); chloride by colorimetric assay; ${ }^{11}$ bicarbonate by Technicon autoanalyser; glucose by a hexokinase-G6PD method; ${ }^{12}$ fructose by initial conversion to glucose 6-phosphate by hexokinase and phosphoglucose isomerase followed by glucose assay, ${ }^{13}$ and polyethylene glycol by a turbidimetric method. ${ }^{14}$ Rates of jejunal and rectal transport were calculated using standard formulae. ${ }^{1015}$ Results for each jejunal perfusate are expressed as the mean of three $\mathbf{1 0}$ minute perfusion periods.

Small intestinal motility tracings were analysed blind, by planimetry, both by the investigator and an independent observer.

\section{Results}

JEJUNAL TRANSPORT (Table 1, Figs 1a and 1b)

At the low perfusate concentration of glucose ( 2 $\mathrm{mmol} / \mathrm{l})$ the jejunum was in a net secretory state with respect to water, sodium, and chloride. At the higher concentration of glucose $(56 \mathrm{mmol} / \mathrm{l})$, water secretion reversed to a small net absorption; in contrast, a secretion of sodium and chloride persisted. Glucose absorption remained intact at

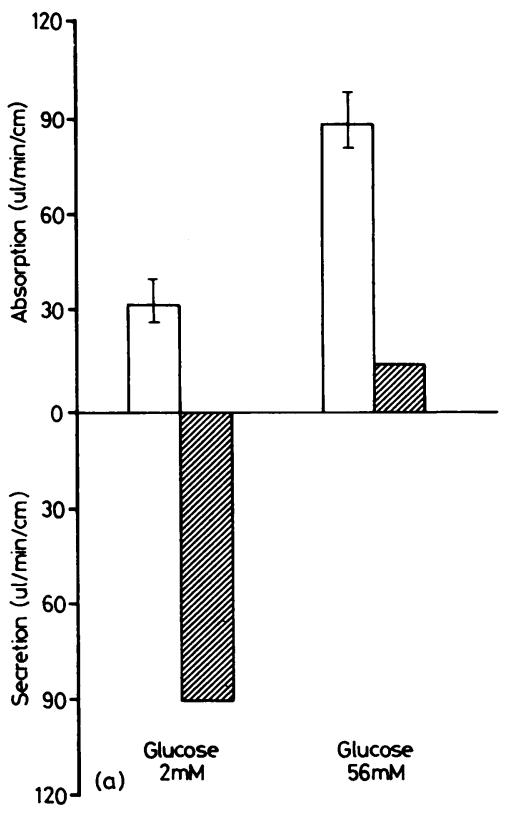

Fig. 1a Net jejunal water transport at perfusate glucose concentrations of $2 \mathrm{mmol} / \mathrm{l}$ and $56 \mathrm{mmol} / \mathrm{l}$ in control children and the patient. Open histograms represent mean values $( \pm S E M)$ obtained in eight controls, and hatched histograms represent values obtained in the patient.

both concentrations of glucose perfused, and did not differ from hexose absorption in the control subjects.

SMALL INTESTINAL MOTILITY (Table 2)

Three abnormalities were present in small intestinal motility. The fasting period was characterised by runs of non-propagated rhythmic contractions and abnormal migrating motor complexes (MMCs). The MMCs were of longer duration and were propagated more slowly than in control children, and unlike controls, could not be disrupted by the instillation of intraduodenal glucose. Finally, random segmenting contractions seen in the controls

Table 1 Net jejunal transport of water, sodium, chloride, and glucose in control children and the patient

\begin{tabular}{|c|c|c|c|c|c|c|c|c|}
\hline \multirow{2}{*}{$\begin{array}{l}\text { Perfusate glucose } \\
\text { (mmolll) }\end{array}$} & \multicolumn{2}{|l|}{$\begin{array}{l}\text { Water } \\
(\mu l)\end{array}$} & \multicolumn{2}{|l|}{$\begin{array}{l}\text { Sodium } \\
\text { ( } \mu \text { mol) }\end{array}$} & \multicolumn{2}{|l|}{ 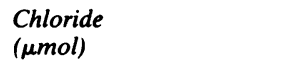 } & \multicolumn{2}{|l|}{ 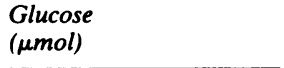 } \\
\hline & 2 & 56 & 2 & 56 & 2 & 56 & 2 & 56 \\
\hline $\begin{array}{l}\text { Controls }(n=8) \\
\text { Patient }\end{array}$ & $\begin{array}{l}+38 \pm 7 \\
-91\end{array}$ & $\begin{array}{l}+89 \pm 10 \\
+10\end{array}$ & $\begin{array}{l}+3.25 \pm 0.61 \\
-4.42\end{array}$ & $\begin{array}{l}+7.65 \pm 1.95 \\
-3.00\end{array}$ & $\begin{array}{l}+2 \cdot 01 \pm 0 \cdot 44 \\
-6 \cdot 10\end{array}$ & $\begin{array}{l}+4.62 \pm 1.00 \\
-4.90\end{array}$ & $\begin{array}{l}+0.54 \pm 0.02 \\
+0.42\end{array}$ & $\begin{array}{l}+9.91 \pm 1.07 \\
+7.31\end{array}$ \\
\hline
\end{tabular}

All results expressed as per min per $\mathrm{cm}$ of jejunum; control values expressed as mean $\pm \mathrm{SEM} ;+=$ net absorption; $-=$ net secretion. 


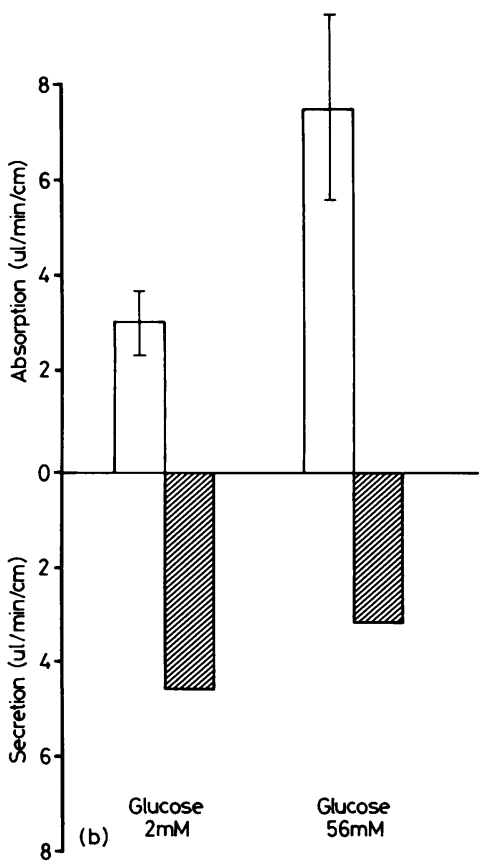

Fig. 1b Net jejunal sodium transport at perfusate glucose concentrations of $2 \mathrm{mmol} / \mathrm{l}$ and $56 \mathrm{mmol} / \mathrm{l}$ in control children and the patient. Open histograms represent mean values ( $\pm S E M)$ obtained in eight controls, and hatched histograms represent values obtained in the patient.

during perfusion with glucose, were not seen in the patient.

RECTAL TRANSPORT AND POTENTIAL DIFFERENCE (Table 3)

Although the values were qualitatively similar in the patient compared with the controls, there were quantitative differences: sodium and chloride absorption were depressed while potassium and
Table 2 Characteristics of migrating motor complexes (MMCs) in control children and in the patient

\begin{tabular}{|c|c|c|c|}
\hline & $\begin{array}{l}\text { Duration } \\
\text { (min) }\end{array}$ & $\begin{array}{l}\text { Interval } \\
\text { between } \\
M M C s \\
(\min )\end{array}$ & $\begin{array}{l}\text { Propa- } \\
\text { gation } \\
\text { velocity } \\
(\mathrm{cm} / \mathrm{min})\end{array}$ \\
\hline $\begin{array}{l}\text { Controls }(n=9) \\
\text { Patient }\end{array}$ & $\begin{array}{l}6 \cdot 1 \pm 0 \cdot 38 \\
11 \cdot 3\end{array}$ & $\begin{array}{l}86 \cdot 6 \pm 16 \cdot 2 \\
86 \cdot 6\end{array}$ & $\begin{array}{l}22 \cdot 8 \pm 4 \cdot 3 \\
2\end{array}$ \\
\hline
\end{tabular}

Control data expressed as mean \pm SEM

bicarbonate secretion, and transmural rectal potential difference were increased.

\section{Discussion}

These results indicate that in our patient with a VIP, calcitonin and catecholamine-secreting tumour, diarrhoea was associated with massive proximal small bowel secretion of water and electrolytes. At low concentrations of glucose $(2 \mathrm{mmol} / \mathrm{l})$ there was marked jejunal secretion of water, sodium, and chloride. At higher concentrations $(56 \mathrm{mmol} / \mathrm{l})$, however, whereas water secretion was reversed to net absorption, sodium and chloride secretion were not reversed. Absorption of glucose was normal at both concentrations. Similar observations have not previously been made in a child with WDHA syndrome.

The striking and intriguing disparity between the effect of glucose on water transport on the one hand, and its effect on sodium and chloride transport on the other, shown in our patient, was also recorded in a similar patient but not commented on by Ramboud et al. ${ }^{7}$ These observations suggest that jejunal permeability to sodium and chloride, but not to water, may be diminished in response to glucoseinduced forces in patients with VIP and calcitoninsecreting tumours. In this context a recent report by Davis et al ${ }^{16}$ may be relevant. These workers infused VIP into human volunteers such that plasma concentrations were in the range found in patients with VIP-secreting tumours, and simultaneously

Table 3 Net rectal transport of sodium, chloride, potassium, bicarbonate, and transmural rectal potential difference in control children and in the patient

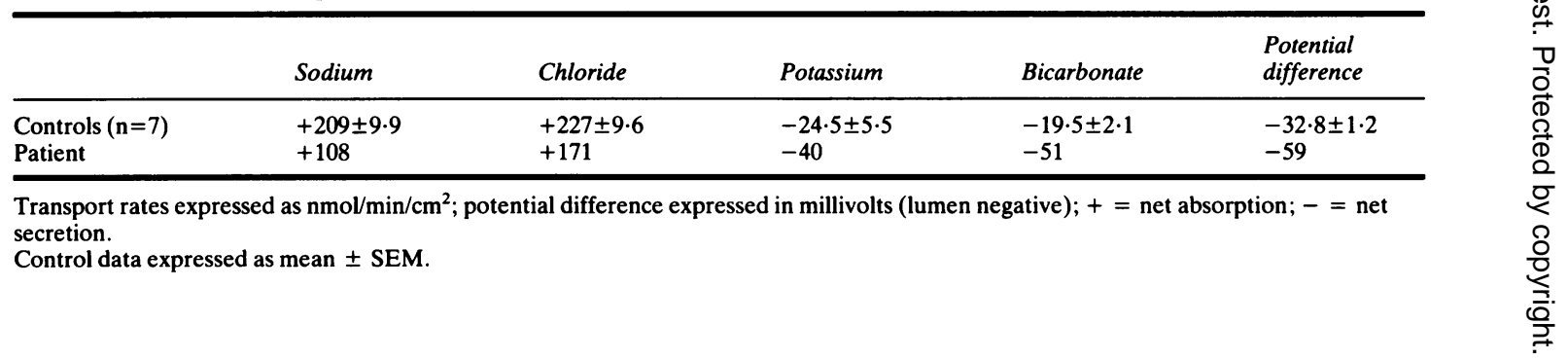


performed steady-state jejunal perfusion studies. They showed not only depression of water, sodium, and chloride absorption but also depression of mannitol-induced secretion of water, sodium, and chloride. On the basis of these results the authors suggest that in the presence of high circulating concentrations of VIP, passive jejunal permeability to water and ions is diminished. The differences between these findings and those in our patient and the one described by Ramboud et ${ }^{7}$ may be related to the elaboration of other secretagogues - for example, calcitonin ${ }^{6}$ - and/or antisecretagogues for example, catecholamines. ${ }^{17}$ It is of interest to note that both of these agents were present in very high concentrations in the plasma of our patient.

Rectal transport studies in our patient showed depression of sodium absorption in the presence of increases in both potassium and bicarbonate secretion, and transmucosal potential difference. Strikingly similar alterations in colonic ion transport, in the presence of a VIP and calcitoninsecreting tumour, have been reported in one previous patient. ${ }^{8}$ While these findings may account for the hypokalaemic acidosis seen in our patient, their explanation remains an anomaly, with the normal physiological exchanges of sodium for potassium, and of chloride for bicarbonate, disrupted by a mechanism which remains speculative.

Whereas the effect of VIP and catecholamine on intestinal smooth muscle has been previously studied in vitro few observations have been made in vivo. VIP ${ }^{18}{ }^{19}$ catecholamines, ${ }^{20}$ and possibly calcitonin ${ }^{21}$ have an inhibitory effect on intestinal smooth muscle and this may be the basis for the absence of postprandial segmenting activity seen in our patient and may also account for the pseudoileus seen in this and previous patients ${ }^{22}$ with VIP. secreting tumours.

The failure of glucose in the duodenum to disrupt the migrating motor complexes together with the absence of segmenting activity during the hexose perfusion may indicate a generalised failure of nutrients to suppress the normal fasting motor activity and induce postprandial activity. This would superimpose an additional factor tending to produce diarrhoea on a pre-existing small bowel secretory state. These observations were made in the presence of normokalaemia following potassium supplementation and it seems likely that in patients with VIP-secreting tumours the abnormal motor activity is due to a direct effect of tumour products on intestinal smooth muscle rather than to the effects of disturbed potassium homeostasis.

Financial support was gratefully received by IWB from the Eden Fellowship of the Royal College of Physicians of London and by TRF from Duphar Laboratories Ltd. We thank Dr S R Bloom and Dr J M Polak of the Royal Postgraduate Medical School, London, for performing measurements of plasma VIP and immunocytochemistry of the tumour respectively.

\section{References}

1 Bloom SR, Polak JM, Pearse AGE. Vasoactive intestinal peptide and watery diarrhoea syndrome. Lancet 1973; 2: 14-16.

2 Said SI, Faloona GR. Elevated plasma and tissue levels of vasoactive intestinal polypeptide in the watery diarrhoea syndrome due to pancreatic, bronchogenic and other tumours. $N$ Engl $J$ Med 1975; 293: 155-60.

3 Bloom SR, Polak JM. The role of VIP in pancreatic cholera. In: Thompson JS, ed. Gastrointestinal hormones. Austin, Texas: University of Texas Press, 1975: 635-42.

4 Modlin IM, Bloom SR, Mitchell SJ. Experimental evidence for vasoactive intestinal peptide as the cause of the watery diarrhoea syndrome. Gastroenterology 1978; 75: 1051-4.

5 Krejs GJ, Fordtran JS. Effect of VIP infusion on water and ion transport in the human jejunum. Gastroenterology 1980; 78: 722-7.

6 Gray TK, Bieberdorf FA, Fordtran JS. Thyrocalcitonin and the jejunal absorption of calcium, water and electrolytes in normal subjects. J Clin Invest 1973; 52: 3084-8.

7 Rambaud JC, Modigliani R, Matuchansky C, Bloom S, Said S, Pessayre D, Bernier JJ. Studies on tumoral secretions and pathophysiology of diarrhoea. Gastroenterology 1975; 69: 110-22.

8 Krejs GJ, Hendler RS, Fordtran JS. Diagnostic and pathophysiologic studies in patients with chronic diarrhoea. In: Field M, Fordtran JS, Schultz SA, eds. Secretory diarrhoea. Bethesda, Maryland: American Physiological Society, 1980: 141-51.

9 Milla PJ, Aggett PJ, Wolff OH, Harries JT. Studies in primary hypomagnesaemia: evidence for defective carrier-mediated small intestinal transport of magnesium. Gut 1979; 20: 1028-33.

10 Edmonds CJ. Absorption of sodium and water by human rectum measured by a dialysis technique. Gut 1971; 12: 356-62.

11 Levinson SS. Direct determination of serum chloride with a semi-automated discrete analyzer. Clin Chem 1976; 22: $273-4$.

12 Barthelmai W, Czok R. Enzymatic determinations of glucose in the blood, cerebrospinal fluid and urine. Klin Wochenschr 1962; 40: 585.

13 Schmidt FH. Enzymatic determination of glucose and fructose simultaneously. Klin Wochenschr 1961; 39: 1244-7.

14 Hyden S. A turbidimetric method for the determina- 
tion of the higher polyethylene glycols in biological materials. K Lantbrhogsk Annlr 1955; 22: 139-45.

15 Sladen GE, Dawson AM. Interrelationships between the absorption of glucose, sodium and water by the normal human jejunum. Clin Sci 1969; 36: 119-32.

16 Davis GR, Santa Ana CA, Morawski SG, Fordtran JS. Effect of vasoactive intestinal polypeptide on active and passive transport in the human jejunum. $J$ Clin Invest 1981; 67: 1687-94.

17 Field M, McColl I. Ion transport in rabbit ileal mucosa. III. Effects of catecholamines. Am J Physiol 1973; 225: 852-7.

18 Strunz U, Mitznegg P, Domschke S, Domsche W, Wunsch E, Demling L. In: Duthie HL, ed. Gastrointestinal motility in health and disease. Lancaster: MTP Press, 1978: 125-31.

19 Kachelhoffer J, Mendel C, Dauchel J, Hohmatter D,
Grenier JF. The Effects of VIP on intestinal motility. Dig Dis 1976; 21: 957-62.

20 Kosterlitz HW, Lydon RJ, Watt AJ. The effects of adrenaline, noradrenaline and isoprenoline on inhibitory alpha and beta adrenoreceptors in the longitudinal muscle of the guinea pig ileum. $\mathrm{Br} J$ Pharmacol 1970; 391: 398-413.

21 Debot J, Coutunier D, Rose C, Debray C. The effect of thyrocalcitonin on pentagastrin-induced contraction of the lower oesophageal sphincter in normals and in patients with achalasia. In: Duthie HL, ed. Gastrointestinal motility in health and disease. Lancaster: MTP, 1977: 341-2.

22 Sircus W, Brunt PW, Walker RJ, Small WP, Falkoner CWA, Thompson CG. Two cases of pancreatic cholera with features of peptide-secreting adenomatosis of the pancreas. Gut 1970; 11: 197-205. 